\title{
Anti-radical and microbial analysis of MAP stored Bitter gourd chips Short-running title: MAP storage study of Bitter gourd chips
}

\author{
Smita Singh ${ }^{1}$, Yogesh Kumar Rathor ${ }^{2}$, Paras Porwal $^{3}$ and Rajendra Kumar Pandey ${ }^{1}$ \\ ${ }^{1}$ Department of Animal Husbandry and Dairying, Institute of Agricultural Sciences, \\ Banaras Hindu University, Varanasi, U.P. 221005, India \\ ${ }^{2}$ Auriga Research Pvt. Ltd., New Delhi-110015, India \\ ${ }^{3}$ DDUKK, Mahatma Gandhi Chitrakoot Gramodaya Vishvavidyalaya, Satna, M.P. 485331, India \\ *Corresponding author
}

\section{A B S T R A C T}

Keywords

Bitter gourd, DPPH, ABTS, TPC, MAP.

Article Info

\section{Accepted:}

26 January 2017

Available Online:

10 February 2017
Bitter gourd (Momordica charantia L.) has been used since long time as food and medicinal plant. This research study was performed to determine the antioxidant activity of the Bitter gourd chips by DPPH radial-scavenging activity and ABTS assay. Total phenolic content was measured by Folin-Ciocalteu reagent. The different MAP gases concentrations used for the packaging of chips were $100 \% \mathrm{~N}_{2}: 0 \% \mathrm{CO}_{2}$, $70 \% \mathrm{~N}_{2}: 30 \% \mathrm{CO}_{2}$ and $50 \% \mathrm{~N}_{2}: 50 \% \mathrm{CO}_{2}$. The temperatures used for storage were at room temperature, $37^{\circ} \mathrm{C}$ and $45^{\circ} \mathrm{C}$. The best result was shown by $100 \% \mathrm{~N}_{2}: 0 \% \mathrm{CO}_{2}$ package stored at room temperature.

\section{Introduction}

India ranks second as the producer of vegetables in the world next to China. 5 to $6 \%$ of the vegetables produced belong to Cucurbitaceae family, commonly called as gourd family (Palamthodi and Lele, 2014). All parts of the plant impart medicinal values and have been used as traditional medicine for the treatment of wound healing, inflammation, hypertension, jaundice, kidney stone, microbial infections, chickenpox, etc. Bitter gourd is a rich source of phenolic compounds. It also possesses high antimutagenic and antioxidant activities. These natural phenolic compounds can be incorporated in many functional food items. Bitter gourd is rich in medicinal value, but due to its bitter taste very few people like to consume it. Today bitter gourd chips have a high selling value. It may be fried or baked with low oil absorption activity with full of health benefits.

The antioxidant activities in fresh fruits and vegetables and their products are being determined by ferric reducing antioxidant power (FRAP) (Benzie and Strain, 1999; Guo et al., 2003; Jimenez-Escrig et al., 2001) oxygen radical absorption capacity (ORAC) (Cao et al., 1993; Ou et al., 2001; Prior et al., 2003), 2,2-azinobis (3-ethyl-benzothiazoline6-sulfonic acid) (ABTS) (Leong and Shui, 2002; Miller and Rice-Evans, 1997) and 2,2diphenyl-1-picrylhydrazyl (DPPH) (BrandWilliams et al., 1995; Gil et al., 2002). 
Today food packaging has emerged as an important criteria regarding food product's sale. The consumer demand for high food quality has increased in the past few years (Callegarin et al., 1997). Modified Atmosphere Packaging has gained a lot of interest with respect to food packaging. It refers as a method where normal gas atmosphere is changed by a package headspace to optimal conditions to extend the shelf-life of packed products. The gases used mainly for MAP technology are carbon dioxide $\left(\mathrm{CO}_{2}\right)$ and nitrogen $\left(\mathrm{N}_{2}\right)$ (Sharma et al., 2016). The objective of this research was to evaluate the anti-radical activity of bitter gourd chips by DPPH and ABTS methods at different MAP gases concentration. In respect of these, total phenolic content and microbial count was also estimated.

\section{Materials and Methods}

Bitter Gourd chips were prepared according to the method explained by Singh et al. (2014). The prepared chips were analyzed for their anti-radical activity by two methods, i.e. DPPH and ABTS at three different concentrations of gases using MAP technology. Further the microbial analysis of chips was done with respect to total bacterial count, total fungal count and coliform count.

\section{Modified atmosphere packaging of chips}

The prepared chips were packaged using MAP at different temperature i.e. room temperature, $37^{\circ} \mathrm{C}$ and $45^{\circ} \mathrm{C}$ in incubators. Different gas concentrations were used i.e. (a) $100 \% \mathrm{~N}_{2}: 0 \% \mathrm{CO}_{2}$ (b) $70 \% \mathrm{~N}_{2}: 30 \% \mathrm{CO}_{2}$ (c) $50 \% \mathrm{~N}_{2}: 50 \% \mathrm{CO}_{2}$.

\section{Anti-radical Activity Determination}

\section{DPPH radical determination}

The DPPH radical scavenging activity of bitter gourd chips was determined according to the methods of Brand-William et al. (1995) with some modifications. Two hundred $\mathrm{mg}$ of sample was taken in centrifuge tube (in triplicate). Two hundred microlitre distilled water was taken in blank instead of the sample. Then $1 \mathrm{ml}$ of DPPH $(8 \mathrm{mg} / 100 \mathrm{ml}$ of ethanol) solution was added to the sample and the blank. This set up was left at room temperature for $30 \mathrm{~min}$ (vortexed in between). Tubes were then centrifuged at $4000 \mathrm{rpm}$ for $10 \mathrm{~min}$. After that, $0.5 \mathrm{ml}$ supernatant was poured in fresh tubes containing $1 \mathrm{ml}$ of ethanol and the absorbance was taken at 517 $\mathrm{nm}$ against the ethanol by using UV1800spectrophotometer (Shimadzu, Japan). Each crude extract was analyzed in triplicate. The percentage of inhibition was calculated against blank.

\section{ABTS radial activity determination}

The ABTS radical scavenging activity of bitter gourd chips was determined according to the methods of Miller et al. (1996) with some modifications. $19.2 \mathrm{mg}$ of ABTS (2, 2azino-bis-3-ethylbenzothialine-6- sulphonic acid) was dissolved in $5 \mathrm{ml}$ of distilled water.1.892 $\mathrm{g}$ of ammonium persulphate was weighed and dissolved in double distilled water and made to $100 \mathrm{ml} .8 \mathrm{~g}$ of $\mathrm{NaCl}, 0.2 \mathrm{~g}$ $\mathrm{KCl}, 1.99 \mathrm{~g}$ of $\mathrm{Na}_{2} \mathrm{HPO}_{4}$ and $0.24 \mathrm{~g}$ of $\mathrm{KH}_{2} \mathrm{PO}_{4}$ were dissolved in $800 \mathrm{ml}$ of double distilled water and $\mathrm{pH}$ was adjusted to 7.2 and final volume was made 1 litre. ABTS working solution was prepared by using $5 \mathrm{ml}$ of $7 \mathrm{mM}$ ABTS stock solution, $88 \mu \mathrm{l}$ of $190 \mathrm{mM}$ ammonium persulphate added in the ratio of 1:0.35 and kept for 12 hour in dark in amber color glass bottle and then diluted (1:70) with buffer till it gives an absorbance of $0.70 \pm$ 0.02 at $734 \mathrm{~nm} .3 \mathrm{ml}$ of ABTS working solution was taken out and mixed with $30 \mu \mathrm{l}$ bitter gourd extracts in $3 \mathrm{ml}$ cuvette. The contents were mixed for 10 seconds. $30 \mu \mathrm{l}$ distilled water was used as blank. Phosphate 
saline buffer was used as reference. After that the absorbance was measured at $734 \mathrm{~nm}$ by using UV-1800spectrophotometer (Shimadzu, Japan) and noted the decrease in absorbance at 10 seconds interval. The percentage of inhibition was calculated against blank.

\section{Total phenolic content}

The total phenolic content of the bitter gourd was determined according to the FolinCiocalteau method as described by Cliffe et al. (1994) with some modifications. Five hundred microlitre of the sample extracts were well mixed with $2.5 \mathrm{ml}$ distilled water, $0.5 \mathrm{ml}$ of $0.2 \mathrm{~N}$ Folin-Ciocalteau reagents and placed for 5 minutes. $1 \mathrm{ml}$ of $75 \mathrm{~g} / \mathrm{l}$ of $\mathrm{Na}_{2} \mathrm{CO}_{3}$ was then added. The above solution was then kept for incubation at room temperature for 30 minutes. Absorbance was measured at $760 \mathrm{~nm}$ using $1 \mathrm{~cm}$ cuvette UV1800spectrophotometer (Shimadzu, Japan). Gallic acid (0 - $800 \mathrm{mg} / \mathrm{L})$ was used to produce standard calibration curve. The total phenolic content was expressed in $\mathrm{mg}$ of Gallic acid equivalents (GAE) per gram of extract.

\section{Determination of microbial population}

The chips were MAP packed by using low density polyethylene bag (LDPE) and stored at room temperature, $37^{\circ} \mathrm{C}$ and $45^{\circ} \mathrm{C}$ for a period of one month (Fig.4). The chips stored at $37^{\circ} \mathrm{C}$ were taken for optimization as they gave best results of storage with less number of microbial counts as compared with chips stored at room temperature and $45^{\circ} \mathrm{C}$.

\section{Statistical analysis}

Significant test and evaluation of MAP stored Bitter gourd chips was done by using Statistical Package for Social Sciences (SPSS).

\section{Results and Discussion}

\section{DPPH Inhibition Activity}

The DPPH inhibition activity of MAP stored bitter gourd chips is presented in (Fig.1) indicated that there was enough difference in the DPPH inhibition activity of bitter gourd chips in all three different concentrations. The antioxidant activity by DPPH inhibition method was higher in $100 \% \mathrm{~N}_{2}$ containing bitter gourd than 70:30 and 50:50 samples. The higher antioxidant activity for chips stored at $100 \% \mathrm{~N}_{2}$ indicated that the samples may retain good medicinal properties when compared to remaining both samples.

Chu et al. (2000) have reported that scavenging activities against DPPH of green leaves of potatoes blanched for $2 \mathrm{~min}$ at $100^{\circ} \mathrm{C}$ remained the same as for fresh ones.

\section{ABTS Inhibition Activity}

The ABTS inhibition activity of prepared bitter gourd chips is presented in Fig.2.The ABTS inhibition activity of chips stored at $100 \% \mathrm{~N}_{2}$ concentration was found to show more inhibition than the chips stored at other concentrations of MAP gases. The ABTS inhibition activity was found to be lower than DPPH inhibition activity at same conditions. The analysis indicated that there was a significant difference in the ABTS inhibition activity among bitter gourd chips at all three concentrations of MAP gases.

\section{Total phenolic content}

Bitter gourd chips stored at $100 \% \quad \mathrm{~N}_{2}$ concentration showed less loss of total phenolic content when compared to chips stored at other concentration of gases (Fig.3). 
Table.1 Microbial counts (total bacterial count, total fungal count and coliform count $\left(\mathrm{cfug}^{-1}\right)$ of modified atmosphere packed bitter gourd chips during storage

\begin{tabular}{|c|c|c|c|}
\hline $\begin{array}{l}\text { Storage Time } \\
\text { (Days) }\end{array}$ & $\begin{array}{l}\text { Total bacterial } \\
\text { Count }\left(10^{-2} \times \mathrm{cfu} / \mathrm{g}\right)\end{array}$ & \begin{tabular}{l} 
Total $\begin{array}{r}\text { Fungal } \\
\text { Count }\left(10^{-2} \times \mathrm{cfu} / \mathrm{g}\right)\end{array}$ \\
\hline 0
\end{tabular} Coliform count & Nil \\
\hline 7 & 0.5 & 3 & Nil \\
\hline 21 & 1.3 & 6 & Nil \\
\hline 30 & 1.8 & 7 & Nil \\
\hline
\end{tabular}

Fig.1 DPPH Inhibition Activity (\%)

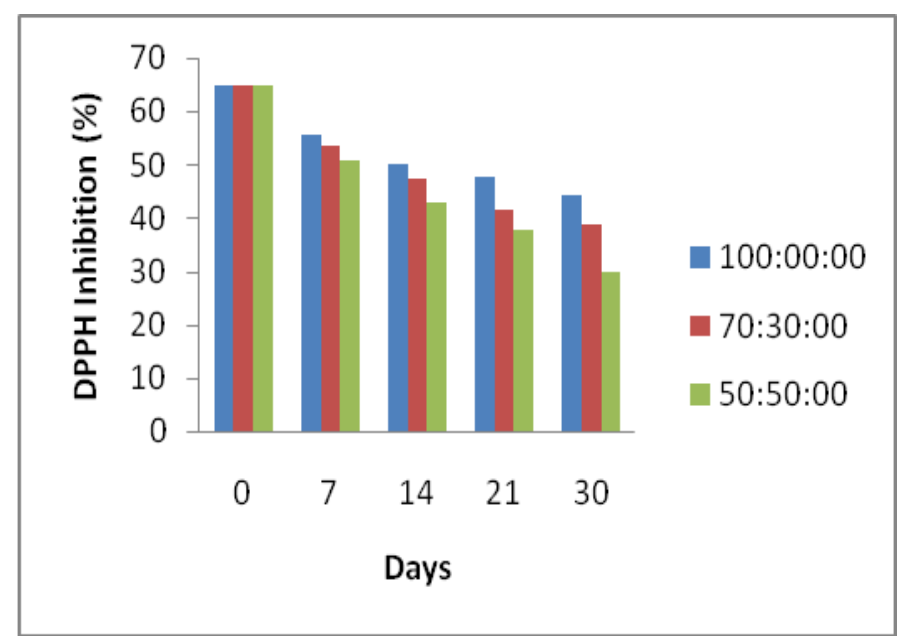

Fig.2 ABTS Inhibition Activity (\%)

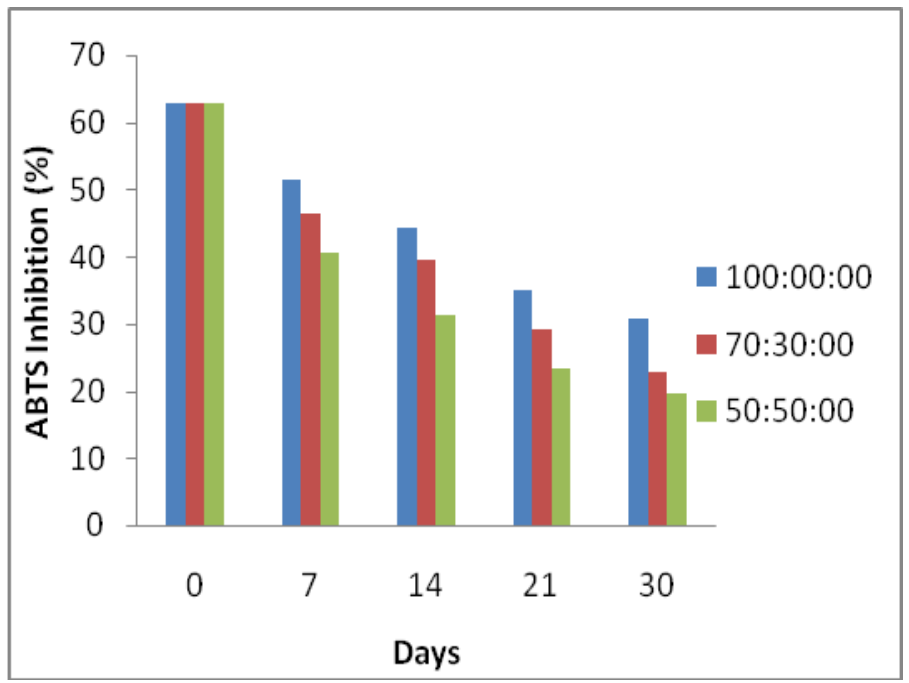


Fig.3 Total phenolic content (mg/g)

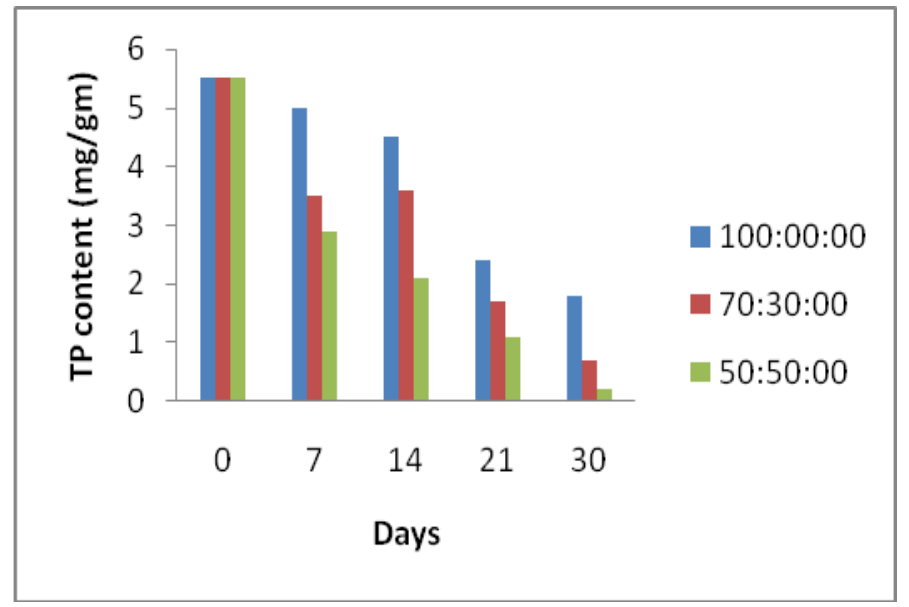

Fig.4 MAP stored Bitter gourd Chips

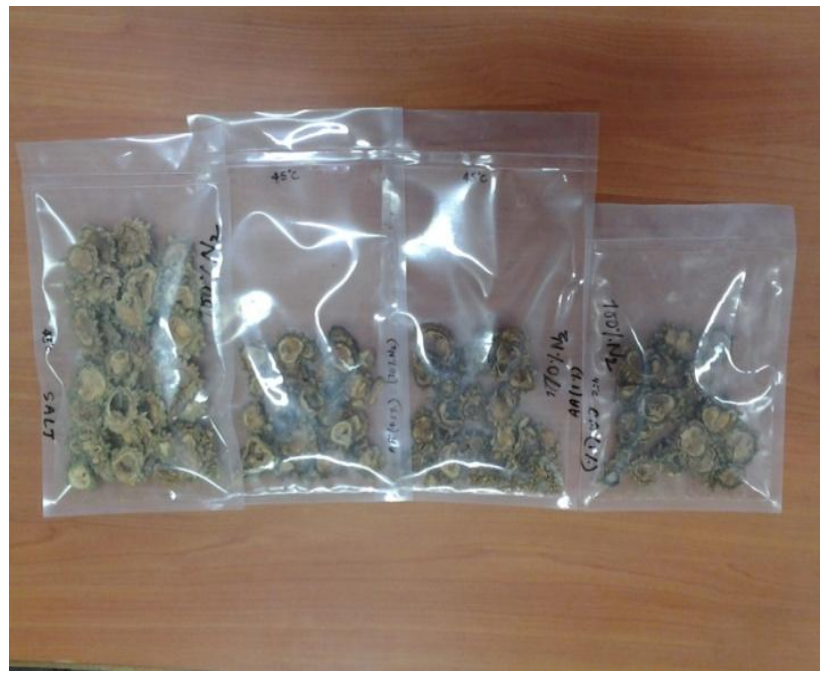

Decreasing temperature of processing was also found to preserve $80-100 \%$ of phenolic content in some vegetables (Roy et al., 2007). Semi drying of tomatoes was found to lower the phenolic content by $30 \%$, but drying of pepper gave contradicting results (Toor and Savage, 2006).

Changes in microbial count of optimized product

All the samples were subjected to microbiological analysis for total plate count
(TPC), yeast and mold count (YMC) and coliform count. The TPC was determined by surface spreading the homogenate with appropriate dilutions $\left(10^{-2}\right)$ on plate count agar (PCA) and incubated at $37{ }^{\circ} \mathrm{C}$ for $24-48$ h. For yeast and mold detection, appropriate dilutions $\left(10^{-2}\right)$ of sample was spread on potato dextrose agar (PDA) and incubated at $25{ }^{\circ} \mathrm{C}$ for $24-48 \mathrm{~h}$. Coliforms in the samples were estimated by plating appropriate dilutions $\left(10^{-2}\right)$ on Violet Red Bile Agar (VRBA) before being incubated at $37{ }^{\circ} \mathrm{C}$ for 24-48 h (AOAC, 2000). The mean total 
bacterial count (TBC) of optimized product increased from 0.5 to $2.5 \times 10^{-2} \mathrm{cfu} / \mathrm{g}$ during storage. It can be observed that the viable count for MAP packed bitter gourd chips increased from $2 \times 10^{-2}$ to $7 \times 10^{-2} \mathrm{cfu} / \mathrm{g}$. The mean coliform count of optimized product was found to be nil during storage (Table 1).

\section{References}

Palamthode, S., Lele, S.S. 2014. Nutraceutical applications of gourd family vegetables: Benincasa hispida, Lagenaria siceraria and Momordica charantia. Biomedicine \& Preventive Nutrition, 4, 15-21.

Benzie, I.F.F., Strain, J.J. 1999. Ferric reducing/antioxidant power assay: direct measure of total antioxidant activity of biological fluids and modified version for simultaneous measurement of total antioxidant power and ascorbic acid concentration. Methods in Enzymology, 299, 15-27.

Guo, C., Yang, J., Wei, J., Li, Y., Xu, J., Jiang, Y. 2003. Antioxidant activities of peel, pulp and seed fractions of common fruits as determined by FRAP assay. Nutr. Res. 23, 17191726.

Jimenez-Escrig, A., Rincon, M., Pulido, R., Saura-Calixto, F. 2001. Guava fruit (Psidium guajava L.) as a new source of antioxidant dietary fiber. J. Agric. Food Chem. 49, 5489-5493.

Cao, G., Alessio, H.M., Cutler, R.G. 1993. Oxygen-radical absorbance capacity assay for antioxidants. Free Radic. Biol. Med. 14, 303-311.

Ou, B., Hampsch-Woodill, M., Prior, R.L. 2001. Development and validation of an improved oxygen radical absorbance capacity assay using fluorescein as the fluorescent probe. J. Agric.Food Chem. 49, 4619-4626.
Prior, R.L., Hoang, H., Gu, L., Wu, X., Bacchiocca, M., Howard, L., Hampsch-Woodill, M., Huang, D., Ou, B., Jacob, R. 2003. Assays for hydrophilic and lipophilic antioxidant capacity (oxygen radical absorbance capacity (ORACFL) of plasma and other biological and food samples. J. Agric. Food Chem. 51, 3273-3279.

Leong, L.P., Shui, G. 2002. An investigation of antioxidant capacity of fruits in Singapore markets. Food Chem. 76, 69-75.

Miller, N.J., Rice-Evans, C.A., 1997. Factors influencing the antioxidant activity determined by the ABTS radical cation assay. Free Radic. Res. 26, 195-199.

Brand-Williams, W., Cuvelier, M. E., Berset, C. 1995. Use of free radical method to evaluate antioxidant activity. Lebensm.-Wiss Technol. 28, 25-30.

Gil, M.I., Tomas-Barberan, F.A., Hess-Pierce, B., Kader, A.A. 2002. Antioxidant capacities, phenolic compounds, carotenoids, and vitamin $\mathrm{C}$ contents of nectarine, peach, and plum cultivars from California. J. Agric. Food Chem. 50, 4976-4982.

Callegarin, F., Quezada-Gallo, J.A., Debeaufort, F., Voilley, A. 1997. Lipids and biopackaging. J. Am. Oil Chem. Soc. 74, 1183-1197.

Sharma, M., Singh, S., Kumar, D., Rathor,Y. K. 2016. Shelf life enhancement of Paneer Tikka by modified atmosphere packaging. J. Pure Appl. Microbio. 10(2): 1415-1420.

Miller, N. J., Sampson, J., Candeias, L.P., Bramley, P.M., Rice-Evans, C.A. 1996. Antioxidant activities of carotenes and xanthophylls. FEBS Letters, 384, 240-242.

Cliffe, S., Fawer, S. M., Maier, G., Takata, K., Ritter, G. 1994. Enzyme assays for the phenolic content of natural juices. 
J. Agric. Food Chem. 42, 1824-1828.

Chu, Y., Chang, C., Hsu, H. 2000. Flavonoid content of several vegetables and their antioxidant activity. J. Sci. Food Agric. 80, 561-566.

Roy, M.K., Takenaka, M., Isobe, S., Tsushida, T. 2007. Antioxidant potential, anti proliferative activities and phenolic content in water-soluble fraction of some commonly consumed vegetables. Effect of thermal treatment. Food Chem. 103, 106-114.

Toor, R.K, Savage, G.P. 2006. Effect of semidrying on the antioxidant components of tomatoes. Food Chem. 94, 90-97.

AOAC, Methods of analysis, $17^{\text {th }}$ edn. Association of official analytical chemistry Washington, USA, 2000.

\section{How to cite this article:}

Smita Singh, Yogesh Kumar Rathor, Paras Porwal and Rajendra Kumar Pandey. 2017. Antiradical and microbial analysis of MAP stored Bitter gourd chips Short-running title: MAP storage study of Bitter gourd chips. Int.J.Curr.Microbiol.App.Sci. 6(2): 1840-1846.

doi: http://dx.doi.org/10.20546/ijcmas.2017.602.207 